\title{
Contractual practices between the consultant and employer in Chinese BIM- enabled construction projects
}

Article

Accepted Version

Liao, X., Lee, C.-Y. and Chong, H.-Y. (2020) Contractual practices between the consultant and employer in Chinese BIM-enabled construction projects. Engineering, Construction and Architectural Management, 27 (1). pp. 227-244. ISSN 0969-9988 doi: https://doi.org/10.1108/ECAM-02-2019-0110 Available at https://centaur.reading.ac.uk/87571/

It is advisable to refer to the publisher's version if you intend to cite from the work. See Guidance on citing.

Published version at: https://www.emerald.com/insight/content/doi/10.1108/ECAM-02-2019-0110/full/html To link to this article DOI: http://dx.doi.org/10.1108/ECAM-02-2019-0110

Publisher: Emerald

All outputs in CentAUR are protected by Intellectual Property Rights law, including copyright law. Copyright and IPR is retained by the creators or other copyright holders. Terms and conditions for use of this material are defined in the End User Agreement.

www.reading.ac.uk/centaur 
Central Archive at the University of Reading

Reading's research outputs online 


\title{
Contractual practices between the consultant and employer in Chinese BIM-enabled construction projects
}

\begin{abstract}
Purpose - The management of building information modeling (BIM)-enabled construction projects is challenging and unstructured in nature, particularly in terms of contract administration. Even though previous studies have revealed various legal issues related to BIM, little is known regarding the contractual practices of BIM. Hence, this study was carried out to explore the contractual practices between the BIM consultant and employer in detail.

Design/methodology/approach — An explanatory case study was carried out on four large BIM-enabled construction projects in China.

Findings - The contractual practices differed from one project to another in terms of ownership and intellectual property rights of the BIM model, roles of the BIM consultant, liability of the BIM consultant in the event of errors and delays of the BIM model, and BIMrelated costs and payments. Some of the interesting findings are as follows: (a) the employer shall retain the ownership and intellectual property rights of the BIM model, (b) the BIM consultant shall provide a warranty to ensure usability of the BIM model after project handover, (c) the BIM consultant shall pay for damages or losses if the BIM model fails to deliver, and (d) the costs of BIM implementation shall be borne by both contracting parties.
\end{abstract}

Originality/value - This study provides a fresh, realistic insight on the development of plausible contractual practices between the BIM consultant and employer and the findings can be used to improve BIM contract protocols in future projects.

Keywords Building information modeling, Contractual practices, Case study, Legal issues, Protocols

Paper type Research paper

\section{Introduction}

A formal contract is a legal instrument that binds the contracting parties with the benefits and obligations stated in the contract. It is important to control, coordinate, and adapt building information modeling (BIM) contractual practices into construction projects (Lee et al., 2018). $\mathrm{BIM}$ is an emerging technology in the architecture, engineering, construction, and operation (AECO) sectors, which requires contracting parties to work cautiously when enforcing contractual terms and conditions (Chong et al., 2017). To facilitate effective BIM implementation, several standard BIM protocols have been developed in the industry, such as the AIA Document E203 ${ }^{\mathrm{TM}}$ - 2013: Building Information Modeling and Digital Data Exhibit (AIA, 2013), ConsensusDocs 301: Building Information Modeling (BIM) Addendum (ConsensusDocs, 2013), CIC Building Information Model (BIM) Protocol: Standard Protocol for Use in Projects using Building Information Models (CIC, 2013), and Complex Projects Contract (CPC, 2013).

Nevertheless, the actual implementation of standard BIM protocols in BIM contracts is still rather low (Al-Shammari, 2014). Previous studies have focused on identifying the legal risks of BIM (Fan et al., 2018; Zhao et al., 2018, legal implications of BIM implementation (Arensman and Ozbek, 2012; Eadie et al., 2014), and adverse legal consequences of BIM contracts (Joyce and Houghton, 2014; Ussing et al., 2016). To date, there are no empirical studies on the detailed contractual practices of BIM, which is primarily due to limited case studies and confidentiality issues of BIM contracts. 
Hence, this study was carried out to explore the key contractual practices between the BIM consultant and employer in detail. The contractual practices covered in this study comprise the ownership and intellectual property rights (IPRs) of the BIM model, roles of the BIM consultant, liability of the BIM consultant in the event of errors and delays of the BIM model, and BIM-related costs and payments, all of which are rarely covered in standard BIM protocols. Comparative analysis was conducted to analyze the contractual practices of four BIM-enabled construction projects in China based on the tender documents of these projects. The tender documents were selected to analyze the contractual practices of BIM at the outset of each project and avoid any conflicts of interests. This study is important to clarify and improve the overall contract administration of BIM-enabled construction projects. This study also identifies good contractual practices of BIM, which can be used as valuable references when devising BIM contracts in the AECO sectors and, hopefully, to promote plausible BIM contractual practices in future construction projects.

\section{Literature review}

BIM has a different contract structure to govern digitalized and collaborative attributes. Even though existing BIM contract protocols provide new perspectives on governing project stakeholders, there are still unclear policies on how to accommodate changes in the project requirements (Redmond et al., 2010). The four key legal aspects concerning BIM implementation are briefly discussed as follows.

\subsection{Ownership and IPRs of the BIM model}

In a BIM collaboration platform, the project team members are required to share their outputs (Ayinla and Adamu, 2018). This raises the issue of who shall own the BIM model and its IPRs in the absence of formal contracts (Larson and Golden, 2007). It has been asserted that the project owner should own the model during the project handover stage (Mordue et al., 2015). However, most of the BIM protocols stipulate that the original contributor should own the model (AIA, 2013; CIC, 2013; ConsensusDocs, 2008). According to Clause 6.2 of the CIC BIM Protocol (CIC, 2013), any rights of the BIM model shall remain vested in the project team member and the project team member shall grant a license to the employer to use the BIM model for the project. Article 2.1 of the AIA Document E203 ${ }^{\mathrm{TM}}$ (AIA, 2013) specifies that the transmitting party is the copyright owner of the digital data. Article 2.3 further specifies that by transmitting the data, it does not convey any ownership rights to use the data unless a license has been granted by the transmitting party to use and modify the data. ConsensusDocs (2008) also adopted a similar approach. However, ConsensusDocs provides a clearer explanation on the copyrights and ownership of the BIM model, which are contributed by multiple parties. Clause 6.1 of ConsensusDocs 301 states that the party is the owner of all copyrights in all that party's contributions or that party is licensed in the contributions to make such contributions. Clause 10.2.2 of the Complex Projects Contract (CPC, 2013) also specifies that the model contributor shall retain the copyright and all other IPRs. Clause 10.2.3 further states that the employer shall be granted a non-exclusive license to use, modify, and reproduce the design for the project.

Since the BIM model is shared between the project team members for various purposes of the project, there is a possibility that a third party may claim infringement against the use of his/her copyright model (Fan, 2014). To prevent such a claim, most of the BIM protocols specify that the model contributor shall grant a license to other project team members to use the BIM model (AIA, 2013; ConsensusDocs, 2008) and no liability shall arise from using the licensed BIM model (CPC, 2013). According to Clause 10.2.1 of the Complex Projects 
Contract (CPC, 2013), the model contributor shall ensure that he/she has the copyright of the BIM model. The model contributor shall indemnify the employer for any losses or damages sustained by the employer due to infringement of copyright and any other IPRs by the model contributor or his/her subcontractor during the design stage. Clause 6.1 of ConsensusDocs 301 (ConsensusDocs, 2008) also highlights the liability of the transmission party, where the transmission party shall indemnify the other party who suffers from losses due to third-party copyright infringement claims.

\subsection{Unclear design delegation}

Common practices require the project designer to design, plan, and develop the built facility throughout the project lifecycle. However, the use of BIM to provide support to the team members, particularly in information transfer, has created new responsibilities for the project designer (Kurul et al., 2013). It is difficult for the project designer to be responsible for creating and maintaining the digital model data, considering that the scope of the work is beyond his/her traditional roles (Simonian and Korman, 2010). Hence, a model manager (known as BIM consultant in the context of this study) may need to be appointed to coordinate model data sharing (Liu et al., 2017) and interdisciplinary collaboration (Jin et al., 2018). ConsensusDocs 301 (ConsensusDocs, 2008) states that the protocol does not restructure the original contractual relationships, which means that those who use the BIM model do not assume any roles other than their traditional roles. However, both the ConsensusDocs 301 (ConsensusDocs, 2008) and Complex Projects Contract (CPC, 2013) require project team members to maintain the integrity of the BIM model. These will indirectly require the project team members such as the project designers to assume additional responsibilities when dealing with the BIM model. Moreover, the unclear responsibilities of the model manager may restrain the full benefits of this role (Liu et al., 2017). The contractual position concerning design delegation varies from one standard BIM protocol to another. In the CIC BIM Protocol (CIC, 2013) and ConsensusDocs 301 (ConsensusDocs, 2008), it is proposed that that the model manager role should be carried out by the project leader, who can be the design consultant or contractor at different stages of the project. A different approach is adopted in the Complex Projects Contract (CPC, 2013), where it is proposed that the design coordination manager should not only coordinate and maintain the BIM model, but also be involved in risk management. In addition, the CIC BIM Protocol (CIC, 2013) specifies that the responsibility to update, review, and maintain the consistency of the protocol shall rest with the information manager. However, ConsensusDocs 301 (ConsensusDocs, 2008) specifies that these responsibilities shall be borne by all participants of the project. Even though BIM simulation software is able to audit the database field, the BIM model still needs to be audited to ensure compliance of the BIM deliverables. Most of the standard BIM protocols exclude this practice except for the Complex Projects Contract (CPC, 2013), which highlights that the project time manager must submit the contractor's design execution plan to the auditor for quality assurance.

\subsection{Liability of the BIM consultant in the event of errors or delays of the BIM model}

The additional roles of delivering the BIM model may potentially alter the standard of care of the project participants (Fan et al., 2018; Jacobsson and Merschbrock, 2018). In this regard, the most critical aspect is the liability of the BIM consultant in the event of BIM delivery errors such as data translation errors, data losses, and model defects. The economic loss of the BIM consultant is only restrained to the software purchasing cost (Pandey et al., 2016). However, if there are any delays in delivering the BIM model, the BIM consultant may have to pay for damages or losses to the employer, which exposes the BIM consultant to higher risks. In 
addition, the non-compliance of preloaded data of the downstream participants may further increase the liability of the BIM consultant in delivering the BIM model on time (Fan et al., 2018). Clause 5.1 of ConsensusDocs 301 (ConsensusDocs, 2008) states that each model contributor shall be responsible for his/her contribution whereas Clause 5.8 states that a time extension shall be granted to the party to rectify the errors resulting from defects of the BIM software. However, such time extensions shall only be limited to losses by the exercise of reasonable care. The Complex Projects Contract (CPC, 2013) has a contrasting position to the former protocol because it requires the contractor to ensure that there will be no potential or actual clashes, conflicts, and errors and the contractor shall be responsible for the integrity and suitability of the selected BIM software. A more lenient approach is adopted in the CIC BIM Protocol (CIC, 2013), where the project team members shall not be liable for any data corruptions except for failure to comply with the protocol. This assumes that the project team members are not liable for the accuracy of the model. This approach is close to the traditional approach of the designer's model, where it is marked "for information purposes only". This provision can lead to inefficiency if the project team members feel that there is a need to verify the integrity of the model in the BIM platform (Udom, 2013).

\subsection{Costs and payments related to the use of BIM in construction projects}

The use of a BIM model incurs various initial and operating costs such as the cost of procuring BIM-related software and hardware, the cost of employing the BIM model, as well as training costs. It is not known whether the project team members are compensated for additional BIMrelated costs (Arensman and Ozbek, 2012). Olatunji (2011) contended that there is a need for an addendum to the professional scales of fees and a standard remuneration needs to be defined for BIM-enabled construction projects. However, according to Arensman and Ozbek (2012), the designer's services are typically billed at an hourly rate and therefore, if the BIM model eventually makes the design process more efficient, this will reduce the number of billable hours. The Complex Projects Contract (CPC, 2013), CIC BIM Protocol (CIC, 2013), and ConsensusDocs 301 (ConsensusDocs, 2008) specify that the employer shall appoint a model manager, which implies that the employer shall be responsible to pay the cost of appointing the model manager. If the employer is responsible for the costs arising from BIM implementation, how shall the payments be made to the model manager? This question has not been defined clearly in the existing standard BIM protocols. Based on the literature review presented in this section, the key contractual practices that need to be explored in the case studies are summarized in Table I.

\section{[Table I]}

\section{Methodology}

The tendering stage is generally the first stage of contract administration and was therefore chosen for this study. In this stage, bidders or BIM consultants will make an offer to the employer of a project based on the prescribed clauses in the tender documents. Although a contract is not officially developed in this stage, most of the clauses in the tender document will form a part of the contract after the award or acceptance of the tender. Hence, an explanatory case study was adopted to analyze the tender documents. It should be noted that because of confidentiality issues, only the tender documents were provided by the employers of the projects for the case study.

As discussed in Section 1, an explanatory case study was chosen as the method to analyze the tender documents between the BIM consultants and employers for four BIM-enabled 
construction projects (herein, named Projects A, B, C, and D). This method is a casual processtracing approach used to attain the predetermined research outcomes (Blatter and Haverland, 2012). In other words, the key contractual practices identified from the four BIM-enabled construction projects were compared with the BIM contractual issues identified from the literature review. The four tender documents were collected from local BIM consultants in China. However, it should be highlighted that not every significant clause was available in the tender documents and the availability of the clauses was subjected to the discretion of the project owners because of data privacy and confidentiality issues. The tender documents were also checked by the BIM consultants to ensure that all confidential and commercially-sensitive information were removed prior to data analysis. To ensure accurate interpretation of terms, the terms were extracted from the tender documents reflected in the actual contractual practices and the outcomes of the analysis were verified by the BIM consultants.

To uphold data reliability and validity, this case study approach collected all necessary project information and participant organizations; certain project characteristics have been summarized in Table II. Projects A and B were infrastructure projects in Beijing and Chongqing, respectively. Both were public-funded projects with tenders started in 2016 and 2014, respectively. For Project A, the BIM consultant was employed by an engineering, procurement, and construction contractor to develop and manage the BIM model, whereas for Project B, the BIM consultant was appointed by the project owner to develop and manage the BIM. Project $C$ involved the construction of an office tower, whereas Project D involved building a shopping complex, both of which were carried out in Chongqing under the design and build procurement system. The BIM consultant for Project $\mathrm{C}$ was appointed by the project owner, whereas the BIM consultant for Project D was employed by a design and building contractor. Projects B, C, and D have been completed successfully. Even though Project A is still ongoing, the work is progressing according to schedule. Joint bidding was not allowed for any of these projects. In addition, a fixed-price contract was used for all projects, where a maximum limit was set by the respective employers. The above information was carefully retrieved and used in this research so as to uphold the anonymity and confidentiality needs required by the participant organizations. The BIM consultants involved in the projects verified and confirmed the accuracy of the data used in the research.

\section{[Table II]}

\section{Results and discussion}

\subsection{Ownership and IPRs of the BIM model}

In this regard, none of the tender documents for Projects A, B, C, and D adopt a similar approach to most standard BIM protocols. Standard BIM protocols state that the natural rights of model ownership shall belong to the model creator. However, this study found that most of the project owners would like to retain the ownership and IPRs of the BIM model. For instance, the terms in the tender documents for Projects A and B state that the IPRs of the BIM model developed for the project shall be owned by the employer and the employer reserves the right to use the BIM software and model provided by the BIM consultant as part of the project permanently. The tender document for Project D makes clear the time frame of the BIM model ownership by emphasizing that the research results and outputs of the BIM model, beginning from receiving the tender document until after award of the contract, shall be owned unconditionally by the contractor. The approach adopted for Project $\mathrm{C}$ is different from those for the other three projects. The terms in the tender document for Project $\mathrm{C}$ state that the employer shall own the final BIM model whereas the IPRs of the BIM model shall belong to 
the BIM consultant. In general, there are a few commendable contractual practices found in these projects. According to the tender document for Project A, the IPRs and the BIM model developed in the project shall be owned by the employer, regardless whether the model and data have been submitted or not. For Project B, the employer shall own the BIM model even if the contract between the employer and BIM consultant has been terminated.

\subsection{Infringement of copyright}

In this regard, all of the projects except for Project D adopt a similar approach to the standard BIM protocols. For Project A, the BIM consultant shall ensure that all of the software, services, and BIM model used and developed during the project do not infringe the lawful rights and interests of the third parties. Any losses suffered by the employer shall be borne by the BIM consultant except for the designs provided by the employer. For Project B, it is stated in the tender document that the losses suffered by the employer due to third-party copyright infringement shall be borne by the BIM consultant. The BIM consultant does not need to compensate the employer of such losses if the BIM consultant creates the designs based on the standard designs supplied by the employer. Because most of the basic designs are provided by the employer and the BIM consultant shall only be responsible to develop the model, the tender document for Project $\mathrm{C}$ specifies that the employer shall indemnify the BIM consultant for any losses due to copyright infringement of the model by the employer. However, there is no information on infringement of copyright in the tender document for Project D.

\subsection{Roles of the BIM consultant}

Most of the standard BIM protocols discussed in Section 2 clearly define the roles of the BIM consultant, particularly in managing and coordinating the BIM models from different design disciplines. These roles are also evident in the tender documents for Projects A, B, C, and D. However, there are additional responsibilities mentioned in the tender documents such as the need for the BIM consultant to form a technical team, which will provide training to the employer's personnel during project handover. The employer of Project A requires the BIM consultant to form a technical team and provide training to the team, which includes but is not limited to the theory of BIM and development and use of BIM model. The BIM consultant shall also provide the courseware, user manuals, and videos demonstrating how to use the BIM model. The employer also requires the BIM consultant to provide training and guidance to professionals from different divisions during the daily project tasks. In contrast, the employer of Project B only requires the BIM consultant to provide training to his/her personnel without any detailed specifications. The employer of Project $\mathrm{C}$ does not specify the training methods; however, the employer requires the BIM consultant to provide training to him/her and the relevant third parties on how to use the BIM software until they are adept with the software. The employer of Project D adopts a similar approach, where the BIM consultant needs to develop and manage his/her own technical team and provide the relevant training to the team. Besides training, the employer of Project A requires the BIM consultant to complete submission to national and international BIM contests. The employer of Project $\mathrm{D}$ also requires the BIM consultant to prepare papers for submission to relevant publications, report the results on BIM implementation, and assist the contractor to win BIM awards at the provincial, ministerial, and national levels in China, as well as at the international level. The employer also requires the BIM consultant to assist the contractor in activities related to BIM demonstration and promotion.

In addition, the employer of Project A expects the BIM consultant to develop a model that can facilitate project management so that the project can be completed according to the budget 
and schedule, and that fulfills the quality desired by the employer. This sets a higher standard of care for the BIM consultant in managing the BIM model. The BIM consultant of Project A needs to ensure that the 4D model developed is updated and improved accordingly as the work progresses. For Project B, the employer sets a time frame to deliver the BIM model at different stages of the project. For instance, the BIM consultant shall submit the as-built BIM model within 90 days after receiving complete information and drawings from the employer and the BIM consultant needs to provide support for maintenance and management of the built facility. The employer of Project $\mathrm{C}$ has higher requirements in terms of time and cost, where the BIM consultant needs to ensure that the project meets the desired quality, safety, and cost according to schedule. In addition, the BIM consultant needs to coordinate the final account settlement and manage the as-built model during the operation and maintenance stage. The employer also requires the BIM consultant to provide the correct types of materials used in the project and accurately estimate the quantities of the construction materials. The BIM consultant shall be responsible for providing reasonable control on the use of materials and ensuring that the accuracy of the cost estimation is at least $97 \%$. The employer of Project $\mathrm{C}$ also requires the BIM consultant to provide a two-year warranty to maintain the BIM model during the project operation stage. The employer of Project D requires the BIM consultant to develop a construction model that reflects the actual situation of the construction site. The BIM consultant shall then establish an effective link between the planned schedule and the actual schedule of the model. The employer requires that the final model should reach a level of development of 500 (i.e., LOD 500) and the BIM consultant needs to establish a project family component library. The BIM consultant is also required to update changes of the model in a timely manner. The roles of the BIM consultant identified from the tender documents of Projects A, B, C, and $\mathrm{D}$ are presented in Table III.

\section{[Table III]}

\subsection{Liability of the BIM consultant in the event of errors or delays of the BIM model}

The employers of most of the projects considered in this study are strict regarding the liability of the BIM consultant in the event of errors or delays of the BIM model. Most of the risks arising from errors or delays of the BIM model and system defects shall be borne by the BIM consultant. For Project A, the BIM consultant shall be responsible for indemnifying the damages or losses suffered by the employer due to changes in the work caused by data translation errors, improper guidance, malfeasance, and other similar issues during BIM implementation. The terms and conditions drafted in the tender document for Project B are more plausible because they do not only state the damages or losses that shall be paid by the BIM consultant, but also the damages or losses that shall be paid by the employer. For Project $\mathrm{B}$, the BIM consultant shall pay for damages or losses to the employer if he/she fails to complete the work within the specified time frame. The compensation fees for damages or losses are calculated on a daily basis based on $0.1 \%$ of the total contract value. The employer shall pay for the damages or losses to the BIM consultant based on a similar calculation method as above if the employer fails to issue payments to the BIM consultant. If the employer fails to pay the BIM consultant after a 30-day period, the BIM consultant is entitled to terminate his/her work with a written notification. The terms and conditions given in the tender document for Project $\mathrm{C}$ differ from those for Projects $\mathrm{A}$ and $\mathrm{B}$ in this regard. For Project $\mathrm{C}$, if the project schedule is delayed and exceeds the agreed deadline, the employer and BIM consultant need to renegotiate on a time extension and agree on the revised contract period. This will enable the BIM consultant to rectify the errors, which may be beyond his/her control. However, the tender document for Project $\mathrm{C}$ also states that the employer is entitled to claim damages or 
losses from the BIM consultant if he/she fails to fulfill the terms and conditions of the contract and causes errors that should be observed in the work. For Project D, if there are any delays (not more than 7 days), the BIM consultant shall pay for damages or losses to the employer, where the compensation fee is $20 \%$ of the total contract value. If the delay is more than 7 days, the total contract value shall be deducted by the employer according to direct and indirect losses incurred to the employer.

\subsection{Costs and payments related to the use of BIM in construction projects}

Not all of the tender documents of the projects considered in this study clearly specify the actual cost of acquiring the copyright of the BIM model. For Project A, the tender document states that if the BIM consultant does not own the corresponding IPRs, the relevant fees for legal acquisition of the IPRs must be included in the contract. For Project B, the tender document states royalties must be paid to use the patented rights of the BIM model and these must be included in the contract. If the employer appoints an agent to manage the selection of a BIM consultant, the BIM consultant is required to pay the agency fees. The tender document of Project B explicitly states that agency fees shall be paid by the selected BIM consultant and these fees shall be included in the contract. However, for Project $\mathrm{C}$, although the tender document specifies that the agency fees for selecting the BIM consultant shall be paid by the selected BIM consultant, there is no information on whether the fees should be included in the contract or not. Regarding training fees, only the tender document of Project A clearly specifies who shall be responsible to pay the training fees. For Project A, the employer shall pay for training his/her personnel on using the BIM software. The training fees include travel and subsistence expenses such as logistics and accommodation associated with training programs. The training provided to the BIM consultant's personnel shall be borne by the BIM consultant.

The tender documents for all projects emphasize that the BIM consultant must consider all the works and risks involved when providing the BIM services. Additional claims after the total contract value has been confirmed are not allowed by the employer. The tender document of Project A specifies that the total contract value shall include office expenditures for the relevant staff, food, and accommodation, licensing cost of using the BIM software, purchasing cost of hardware, transportation cost, cost of research and development, software and hardware upgrading fees, necessary fees for BIM specialists, and conference fees. All of these fees must be included in the quotation. Labor costs, on-site service fees, and other related fees such as the costs of telephone, fax, cartography, and postal mail, as well as all technical and after-sales service fees, must also be included in the contract. If the service involves software licensing, technical guidance, or personnel training, the contract should also include the relevant fees. To obtain better clarity in the quotation submitted by the BIM consultant, the employer requests that the BIM consultant submit a detailed list of the BIM services provided and their prices. All items concerning the services and scope of work deemed necessary by the BIM consultant but not listed in the tender document should be supplemented after the quotation form and the supplementary materials must be stated separately.

Similar to the tender document of Project A, the contract price should include all of the fees for the services provided by the BIM consultant. The contract price of Project B should cover personnel and transportation costs, taxes, management fees, profits, risks, and all other factors related to the BIM implementation. A similar approach was also adopted for Projects $\mathrm{C}$ and $\mathrm{D}$, where the employer of Project $\mathrm{C}$ requires that the contract price should include all of the fees for BIM consultation services and other costs for BIM implementation. The contract price is not limited to employee insurance, medical insurance, travel insurance, project postings, profit management fees, profit taxes, testing fees, cost of testing equipment, cost of tools and other 
equipment, cost of office supplies, transportation taxes, security cost, maintenance cost of the BIM platform during the two-year warranty period, and modification costs for repeated design and construction models. The employer of Project D requires the BIM consultant to consider existing support provided by the contractor such as data translation of different software, their connections, design models, resources, and information management when submitting his/her quotation in the tender document. The tender document of Project D stresses that the contract price is fixed. The contract price shall not be adjusted even if the scope of work increases or decreases, or if there are any changes in the scope of work due to construction conditions or other factors. This term is not apparent in the tender documents for other projects.

\subsection{Payments to the BIM consultant}

Most of the projects require the BIM consultant to provide a performance bond. For Project A, the BIM consultant shall provide the contractor with a performance bond worth $10 \%$ of the contract value within 30 days upon receiving the letter of acceptance. The performance bond shall only be returned to the BIM consultant after all of the required BIM deliverables have been submitted and verified by the employer of the project. However, for Project B, the BIM consultant does not need to provide a performance bond. For Project $\mathrm{C}$, the performance bond is worth $5 \%$ of the total contract value. The performance bond will end after 20 days following the end of the warranty period. The performance bond shall be submitted within 10 days after receiving the letter of acceptance. The employer reserves the right to appoint a third party at any time to audit the BIM deliverables. If the deliverables do not qualify, the contractor reserves the right to terminate the contract and request the BIM consultant to pay for damages or losses and at the same time, the BIM consultant's full performance bond will not be refunded. During the two-year warranty period, the BIM consultant is required to send his/her technical team to fix any problems with the BIM model after receiving a notice from the employer. The employer shall not bear the expenses incurred to fix the problems. The BIM consultant is also required to provide free upgrades of the relevant systems and software during the warranty period. After the warranty period, the BIM consultant is required to provide a positive response upon receiving a notice from the client pertaining to the BIM model or system or if there is a need to upgrade. In such cases, the BIM consultant is required to provide discounts for such fees. After the warranty period, the BIM consultant is encouraged to provide lifetime maintenance of the BIM product such as providing upgrade services for equipment and systems. For Project D, the BIM consultant is required to pay a performance bond worth $5 \%$ of the total contract value within 7 days upon receiving the letter of acceptance of the tender.

It is evident from the results that the terms and conditions in the tender documents differ from one project to another in terms of payments to the BIM consultant. Nevertheless, Projects A, B, C, and D share a similar contractual practice, where progressive payments are made to the BIM consultant according to the milestones achieved, as stated in the contract. Only the tender documents of Projects A and B clearly state advance payment terms. For Project A, 10\% of the total contract value shall be paid as an advanced payment to the BIM consultant within 7 days upon receiving the performance bond. For Project A, progress payments shall be made to the BIM consultant based on the tasks defined in the contract. The progress payments shall also be made to the BIM consultant based on claims (including new claims, outstanding and past due invoices), completed tasks and their outcomes, recoupment of advance payments, as well as setoff. The employer also requires the BIM consultant to include the actual completed work and planned work. This is a commendable practice because it ensures that the BIM consultant will always be aware of his/her work progress and ensure that the BIM deliverables are submitted in a timely manner. For Project B, 35\% of the total contract value shall only be 
paid to the BIM consultant after he/she submits the 4D construction plan, which indicates the sequence of construction. In addition, $25 \%$ of the total contract value shall be paid after the BIM consultant oversees the project operations to completion. The balance of the total contract value shall be paid after the BIM consultant submits the as-built BIM model and provides BIMrelated training to the employer's personnel. The payment terms for Project B are more reasonable compared with those for Project D, where the BIM consultant is entitled to adjust the original contract price if the scope of work changes by more than $20 \%$ of the original scope of work.

The payment terms for Project $\mathrm{C}$ are more detailed, including liquidated and ascertained damages for the party who fails to make payments and thus, breaches the contract. If the BIM consultant fails to submit the BIM model on time as agreed in the contract, the BIM consultant shall pay the project owner for damages or losses on a daily basis based on $0.05 \%$ of the total contract value. If the overdue period is more than 20 days, the employer reserves the right to terminate the contract. If the employer fails to make payments to the BIM consultant, the employer is required to pay the outstanding payments inclusive of interest. This interest will be calculated based on the latest base lending rate multiplied by the outstanding payment owed to the BIM consultant. If the employer has objections on any part of the claim submitted by the BIM consultant, the employer must send a notice of opposition to the BIM consultant within 7 days of receiving the payment notice. However, the employer must not delay payments for parts of the claim without objections. For progressive payments, different percentages are allocated to different types of works. For instance, $20 \%$ of the total contract value shall be paid to the BIM consultant after receiving the BIM model, which comprises the architectural, structural, mechanical, and electrical models during the design stage and clash detection reports. Next, $60 \%$ of the total contract value shall be paid to the BIM consultant for the BIM model developed during the construction and tendering stage for civil construction, curtain walls, heat, ventilation, and air-conditioning, elevators, electricity, water supply and drainage, fire protection, and interior decoration. During the project handover, the BIM consultant shall be paid $5 \%$ of the total contract value after he/she has submitted the as-built BIM model and provided training to the employer's personnel. During the maintenance and operation stage, the BIM consultant shall be paid 5\% of the total contract value after providing training to the project owner and property management company. After the end of the two-year warranty period, the remaining balance shall be paid to the BIM consultant, which is $10 \%$ of the total contract value. Another commendable contractual practice for Project $\mathrm{C}$ is that the tender document states the rights of the BIM consultant if the work is terminated due to defaults by the employer. In such cases, the BIM consultant reserves the right to claim additional fees from the employer for restoration of the work.

The payment terms are not specified in detail in the tender document for Project D. For this project, the BIM model developed by the BIM consultant is directly related to the actual work done on-site. Hence, payment shall only be made when the BIM consultant completes the BIM model according to the timeline agreed in the contract, which is verified by the employer. The tender document also states that if the work done by the BIM consultant does not meet the expected quality required by the employer according to schedule, the employer reserves the right to remove the works from the list that are required to be completed by the BIM consultant. The removal of works will not affect the remaining works in the contract.

Table IV summarizes the main findings and commendable practices for the six important contractual practices described above, based on the four case studies. Overall, the case studies render new and realistic contractual insights into risk allocation in BIM-enabled construction projects. Regardless of the project sizes, types, or procurement systems, the new digitalized practices in BIM have fostered a new contractual arrangement between the BIM consultant and the employer in terms of their parties' rights, obligations, and liabilities. Although publicly 
funded BIM-enabled projects have more detailed contractual requirements to safeguard the employer's interests, privately funded projects have also used clear and professional contractual practices to govern their BIM-enabled construction projects. Many new and practical examples of BIM contractual practices have been identified, which can be generalized and used as valuable references in contract administration for all BIM-enabled projects. They also can be referred to for future development of BIM contract protocols.

\section{[Table IV]}

\section{Conclusions and recommendations for future work}

In this study, an exploratory case study was carried out to assess the details of contractual practices for BIM-enabled construction projects in China based on four projects: Project A (infrastructure project in Beijing), Project B (infrastructure project in Chongqing), Project C (construction of office tower in Chongqing), and Project D (construction of shopping complex in Chongqing). Four key contractual practices were identified from the tender documents of these projects: (1) ownership and IPRs of the BIM model, (2) roles of the BIM consultant, (3) liability of the BIM consultant in the event of errors and delays of the BIM model, and (4) BIM-related costs and payments.

In terms of the ownership and IPRs of the BIM model, most of the employers require that they retain the ownership and IPRs of the BIM model as they need the BIM model after project handover to maintain and operate the built facility. Only the tender document for Project $\mathrm{C}$ clearly states that the IPRs shall remain vested in the BIM consultant and the final BIM model shall be owned by the employer. This contrasts with the terms stipulated in most of the standard BIM protocols, where the project designers shall be the copyright owners of the BIM model. The employers for Projects A, B, C, and D require the BIM consultant to pay for damages or losses due to third-party copyright infringement of the BIM model. This is similar to the approaches in standard BIM protocols.

In terms of the roles of the BIM consultant, the tender documents of Projects A, B, C, and D highlight that the BIM consultant shall not only manage and coordinate the BIM model, but he/she shall also ensure that the BIM model delivered is accurate and updated accordingly in a timely manner. In other words, the BIM consultant shall also be liable for damages or losses if there are delays in works due to delays of delivering the BIM model. The employers also require the BIM consultant to provide training to the employer's personnel and provide warranty after project handover.

In terms of BIM-related costs and payments, the employer of Project $\mathrm{C}$ requires the BIM consultant to ensure that the accuracy of cost estimation is at least $97 \%$. This sets a higher standard for the BIM consultant and therefore, the BIM consultant is responsible for developing and updating the BIM model in a timely manner. In terms of who shall bear the cost of BIM implementation, most of the BIM-related costs are covered by the employer of the project except for the training provided by the BIM consultant to the employer's personnel. In this case, the cost of using the BIM model is shared by the employer and BIM consultant.

Some contractual practices are especially noteworthy. For example, advance payment is an ideal payment option for the BIM consultant, who bears a significant portion of the cost for BIM implementation at the outset of the project. Although the payment terms differ for Projects $\mathrm{A}, \mathrm{B}, \mathrm{C}$, and D, progressive payments are made according to predefined project milestones, which provides a clear guideline to the BIM consultant for claims during project implementation. When devising the terms concerning the ownership and IPRs of the BIM model, it is desirable if the contract terms clearly state the commencement of the ownership of 
the BIM model. For example, the tender document of Project A states that the ownership and IPRs of the BIM model shall be granted to the employer, regardless of whether the BIM model and all associated data have been submitted or not. In the event of contract termination between the employer and BIM consultant, it is stated in the tender document for Project B that the BIM model shall be owned by the employer. The tender document of Project B also states that the BIM consultant is required to include his/her actual work done and planned work in claim submissions, which is indeed a commendable contractual practice. This creates awareness for the BIM consultant such that he/she will ensure that the BIM deliverables are submitted in timely manner. The terms presented in the tender documents for Projects A and B are also good contractual practices, where the relevant fees for legal acquisition of the IPRs need to be included in the contract. The terms devised in the tender document for Project $\mathrm{C}$ are more equitable. The terms do not only specify the rights of the employer but also the rights of the BIM consultant when either party fails to fulfill his/her obligations. In addition, the terms for Project $\mathrm{C}$ include the rights of the employer to appoint a third party to audit the BIM deliverables at different stages of the project. This practice is exemplary as it helps ensure conformance of the deliverables, considering that the BIM model developed will influences the overall project deliverables. In this manner, the project can be completed according to budget and schedule and fulfills the quality desired by employer.

Although a number of good contractual practices of BIM have been identified from the explanatory case study, there are also a few limitations. Because the contractual practices were assessed based on the tender documents of the BIM-enabled construction projects, the detailed contractual practices typically available in BIM contracts were not determined in this study. In addition, only four key contractual practices were discussed in this paper. Hence, future studies can be carried out to elicit information on the employer's requirements on the BIM consultant and from here, the appropriate strategies can be proposed to facilitate the BIM consultant to fulfill the requirements. These actions of contractual improvement should be confirmed and tested across the industry through a questionnaire survey approach with rigorous statistical analyses. In addition, this study is only focused on comparing the contractual practices of four BIM-enabled construction projects in China and it is very likely that the contractual practices in other regions or countries may be different, which will require further investigation.

This study extends the current body of knowledge related to contract administration of BIMenabled construction projects and existing standard BIM protocols. A number of new and potential contract provisions for BIM contracts have been identified in terms of the ownership and IPRs of the BIM model, the roles of the BIM consultant, the liability of the BIM consultant in the event of errors and delays of the BIM model, and BIM-related costs and payment. It is believed that the findings presented in this paper will be useful to promote and standardize future BIM-oriented contract administration in AECO sectors.

\section{References}

AIA (2013). Building information modelling and digital data exhibit (Document E203TM). The American Institute of Architects, United States.

Al-Shammari, M A (2014). "An appraisal of the protocol that was published by the construction industry council (CIC) to facilitate the use of building information modelling (BIM) on projects." In: Raiden, A B and Aboagye-Nimo, E (Eds) Procs 30th Annual ARCOM Conference, 1-3 September 201 4, Portsmouth, UK, Association of Researchers in Construction Management, 623-632. 
Akinsola, A.O., Potts, K.F., Ndekugri, I. and Harris, F.C. (1997), "Identification and evaluation of factors influencing variations on building projects", International Journal of Project Management, Vol. 15 No. 4, pp. 263-267, doi: 10.1016/S0263-7863(96)00081-6.

Alarcón, L.F., Grillo, A., Freire, J. and Diethelm, S. (2001), "Learning from collaborative benchmarking in the construction industry", Proceeding 9th Annual Conference of the International Group for Lean Construction (IGLC), Singapore, July.

Albertin, M.R., Pontes, H.L.J., Frota, E.R. and Assunção, M.B. (2015), "Flexible benchmarking: a new reference model", Benchmarking: An International Journal, Vol. 22 No. 5, pp. 920-944.

Alharbi, M., Emmitt, S. and Demian, P. (2015a), "Transferring architectural management into practice: a taxonomy framework", Frontiers of Architectural Research, Vol. 4 No. 3, pp. 237-247, available at: http://doi.org/10.1016/j.foar.2015.04.001

Alharbi, M., Emmitt, S. and Demian, P. (2015b), "What is architectural management? Towards a pragmatic definition", Engineering. Construction and Architectural Management, Vol. 22 No. 2, pp. 151-168, available at: http://doi.org/10.1108/ECAM-05-2014-0068

Arensman, D. B., and Ozbek, M. E. (2012). "Building information modelling and potential legal issues." Int. J. Constr. Education \& Research, 8, 146-156.

Ayinla, K. O., \& Adamu, Z. (2018). Bridging the digital divide gap in BIM technology adoption. Engineering, Construction and Architectural Management, 25(10), 13981416.

Blatter, J., and Haverland, M. (2012). Designing case studies: Explanatory approaches in small-N research. Palgrave Macmillan.

Bloom, N., Eifert, B., Mahajan, A., McKenzie, D. and Roberts, J. (2012), "Does management matter? Evidence from India”, The Quarterly Journal of Economics, Vol. 128 No. 1, pp. 1-51, available at: http://doi.org/10.1093/qje/qjs044

Broderick, A., Garry, T. and Beasley, M. (2010), "The need for adaptive processes of benchmarking in small business-to-business services", Journal of Business \& Industrial Marketing, Vol. 25 No. 5, pp. 324-337, available at: http://doi.org/10.1108/08858621011058098

Castillo, T., Alarcón, L.F., Salvatierra, J.L. and Alarcón, D. (2015), "Analyzing the interrelation between management practices. organizational characteristics and performance indicators for construction companies", Proceedings 23th Annual Conference of the International Group for Lean Construction (IGLC), Perth, pp. 691700.

Chan, D.W. and Kumaraswamy, M.M. (1997), "A comparative study of causes of time overruns in Hong Kong construction projects", International Journal of Project Management, Vol. 15 No. 1, pp. 55-63.

Chong, H. Y., Fan, S. L., Sutrisna, M., Hsieh, S. H., \& Tsai, C. M. (2017). Preliminary contractual framework for BIM-enabled projects. Journal of Construction Engineering and Management, 143(7), 04017025.

CIC. (2013). CIC BIM Protocol. Construction Industry Council, United Kingdom.

ConsensusDocs (2008). Building Information Modelling (BIM) Addendum. ConsensusDocs 301. United States.

CPC (2013). Contract for complex projects. Chartered Institute of Building, United Kingdom.

Demkin, J.A. (2008), in American Institute of Architects (Ed.), The Architect's Handbook of Professional Practice, 14th ed., Wiley \& Sons, NJ, p. 1028.Eadie, R., Odeyinka, H., Browne, M., McKeown, C., and Yohanis, M. (2014). "Building information modelling adoption: an analysis of the barriers to implementation." J. Eng. \& Architecture, 2(1), 77-101. 
Fan, S. L. (2014). "Intellectual property rights in building information modelling application in Taiwan." J. Constr. Eng. Manage., 140(3), 04013058, 1-6.

Fan, S. L., Lee, C. Y., Chong, H. Y., \& Skibniewski, M. J. (2018). "A critical review of legal issues and solutions associated with building information modelling." Techno. Econ. Dev. Econ., 24(5), 2098-2130.

Jacobsson, M., \& Merschbrock, C. (2018). BIM coordinators: a review. Engineering, Construction and Architectural Management, 25(8), 989-1008.

Jin, R., Yang, T., Piroozfar, P., Kang, B. G., Wanatowski, D., Hancock, C. M., \& Tang, L. (2018). Project-based pedagogy in interdisciplinary building design adopting BIM. Engineering, Construction and Architectural Management, 25(10), 1376-1397.

Joyce, R., and Houghton, D. (2014). "Briefing: building information modelling and the law." Proceedings of the Institution of Civil Engineers Management, Procurement and Law, 167(3), 114-116.

Kurul, E., Abanda, H., Tah, J., and Cheung, F. (2013). "Rethinking the build process for BIM adoption." Paper presented at CIB World Building Congress. Brisbane, Australia.

Larson, D. A., and Golden, K. A. (2007). "Entering the brave new world: an introduction to contracting for BIM." William Mitchell Law Review, 34(1), 75-108.

Lee, C. Y., Chong, H. Y., and Wang, X. (2018). "Enhancing BIM Performance in EPC Projects through Integrative Trust-Based Functional Contracting Model." J. Constr. Eng. Manage., 144(7), 06018002.

Liu, Y., Van Nederveen, S., and Hertogh, M. (2017). "Understanding effects of BIM on collaborative design and construction: an empirical study in China." Int. J. Proj. Manage., 35(4), 686-698.

Mordue, S., Swaddle, P., and Philp, D. (2015). "BIM for Dummie.” West Sussex, UK: John Wiley \& Sons.

Pandey, A., Shahbodaghlou, F., and Burger, J. (2016). "Legal and contractual challenges of Building Information Modeling - designers' perspectives.” In Construction Research Congress, pp. 519-527. American Society of Civil Engineers

Simonian, L., and Korman, T. (2010). "Legal considerations in the United States associated with Building information modeling." The Construction, Building and Real Estate Research Conference of the Royal Institution of Chartered Surveyors, RICS COBRA. Dauphine Université Paris, France.

Udom, K. (2013). The CIC BIM Protocol - a critical analysis. NBS. Retrieved from https://www.thenbs.com/knowledge/the-cic-bim-protocol-a-critical-analysis.

Ussing, L. F., Svidt, K., and Wandahl, S. (2016). Legal Aspects Connected to the Use of BIM in the Danish Building Sector. In Construction Research Congress 2016, 528-537. American Society of Civil Engineers.

Zhao, X., Wu, P., \& Wang, X. (2018). "Risk paths in BIM adoption: empirical study of China." Engineering, Construction and Architectural Management, 25(9), 1170-1187. 
Table I. Key contractual practices of BIM

\begin{tabular}{|c|c|c|}
\hline No. & Key contractual practices & References \\
\hline 1. & $\begin{array}{l}\text { Ownership and IPRs of the BIM } \\
\text { model }\end{array}$ & \\
\hline a. & Who shall own the BIM model? & $\begin{array}{l}\text { Arensman and Ozbek (2012), Eadie et al. } \\
\text { (2014), Fan et al. (2018, 2014), , Larson and } \\
\text { Golden (2007), Mordue et al. (2015) }\end{array}$ \\
\hline b. & Infringement copyright & \\
\hline 2. & Roles of the BIM consultant & \\
\hline a. & $\begin{array}{l}\text { What are the employer's } \\
\text { requirements on the roles of the BIM } \\
\text { consultant? }\end{array}$ & $\begin{array}{l}\text { Kurul et al. (2013), Liu et al. (2017), } \\
\text { Simoniam and Korman (2013) }\end{array}$ \\
\hline 3. & $\begin{array}{l}\text { Liability of the BIM consultant in the } \\
\text { event of errors or delays of the BIM } \\
\text { model }\end{array}$ & Fan et al. (2018), Pandey et al. (2016) \\
\hline 4. & $\begin{array}{l}\text { Costs and payments related to the use } \\
\text { of BIM in construction projects }\end{array}$ & \\
\hline a. & $\begin{array}{l}\text { Who shall bear the costs of BIM } \\
\text { implementation? }\end{array}$ & Arensman and Ozbek (2012) \\
\hline b. & $\begin{array}{l}\text { How shall the payments be made to } \\
\text { the BIM consultant? }\end{array}$ & Fan et al. (2018) \\
\hline
\end{tabular}


Table II. Characteristics of the four BIM-enabled construction projects considered in this study

\begin{tabular}{|c|c|c|c|c|c|c|c|c|c|}
\hline Project & Project type & Client & Location & $\begin{array}{l}\text { Estimated } \\
\text { project } \\
\text { value } \\
\text { (USD) }\end{array}$ & $\begin{array}{l}\text { Duration } \\
\text { of project }\end{array}$ & $\begin{array}{l}\text { Year of } \\
\text { tender }\end{array}$ & Procurement system & $\begin{array}{l}\text { Contract } \\
\text { Type }\end{array}$ & $\begin{array}{l}\text { Status of } \\
\text { project }\end{array}$ \\
\hline A & Infrastructure & Public & Beijing & 1 billion & 3 years & 2016 & $\begin{array}{l}\text { Engineering, } \\
\text { procurement and } \\
\text { construction system }\end{array}$ & $\begin{array}{l}\text { Fixed-price } \\
\text { contract }\end{array}$ & $\begin{array}{l}\text { Ongoing and } \\
\text { on schedule }\end{array}$ \\
\hline B & Infrastructure & Public & Chongqing & 1 billion & 3 years & 2014 & $\begin{array}{l}\text { Project management } \\
\text { consultant }\end{array}$ & $\begin{array}{l}\text { Fixed-price } \\
\text { contract }\end{array}$ & $\begin{array}{l}\text { Completed } \\
\text { on time }\end{array}$ \\
\hline $\mathrm{C}$ & Office tower & Private & Chongqing & 150 million & 3 years & 2014 & Design and build & $\begin{array}{l}\text { Fixed-price } \\
\text { contract }\end{array}$ & $\begin{array}{l}\text { Completed } \\
\text { on time }\end{array}$ \\
\hline $\mathrm{D}$ & $\begin{array}{l}\text { Shopping } \\
\text { complex }\end{array}$ & Private & Chongqing & 300 million & 3 years & 2015 & Design and build & $\begin{array}{l}\text { Fixed-price } \\
\text { contract }\end{array}$ & $\begin{array}{l}\text { Completed } \\
\text { on time }\end{array}$ \\
\hline
\end{tabular}


Table III. Roles of the BIM consultant identified from the tender documents for Projects A, B, C, and D

\begin{tabular}{|c|c|c|c|}
\hline Project A & Project B & Project C & Project D \\
\hline The BIM consultant shall: & The BIM consultant shall: & The BIM consultant shall: & The BIM consultant shall: \\
\hline $\begin{array}{l}\text { 3. manage model development } \\
\text { and maintain the BIM } \\
\text { model, which includes } \\
\text { providing genuine BIM } \\
\text { software, server } \\
\text { configuration, and } \\
\text { installation for the client. }\end{array}$ & $\begin{array}{l}\text { 2. develop a 4D simulation } \\
\text { model based on the } \\
\text { construction technology, } \\
\text { construction plan, and } \\
\text { prefabricated component } \\
\text { application to assist the } \\
\text { construction party to carry }\end{array}$ & $\begin{array}{l}\text { 2. ensure that the project achieves } \\
\text { the desired quality and safety } \\
\text { according to schedule and } \\
\text { budget, coordinate the final } \\
\text { account settlement, and manage } \\
\text { the as-built BIM model during } \\
\text { the operation and maintenance }\end{array}$ & $\begin{array}{l}\text { information delivery, and } \\
\text { model exchange to meet the } \\
\text { functional requirements of } \\
\text { each application system. } \\
\text { 2. develop the BIM model that } \\
\text { reflects the actual situation of } \\
\text { the construction site. }\end{array}$ \\
\hline $\begin{array}{l}\text { 4. coordinate and } \\
\text { communicate with the BIM } \\
\text { participants during the } \\
\text { model development process } \\
\text { and continue to improve the } \\
\text { BIM platform based on the } \\
\text { contractor's requirements. }\end{array}$ & $\begin{array}{l}\text { 3. submit the BIM model to } \\
\text { the employer to be } \\
\text { distributed to each } \\
\text { construction unit. }\end{array}$ & $\begin{array}{l}\text { stage. } \\
\text { 3. ensure the quality of the BIM } \\
\text { deliverables for project } \\
\text { handover, operation, and } \\
\text { maintenance. } \\
\text { 4. cooperate with an engineering } \\
\text { consulting firm to develop bills }\end{array}$ & $\begin{array}{l}\text { 3. review the developed BIM } \\
\text { model to ensure it fulfills the } \\
\text { standard requirements. } \\
\text { 4. integrate the BIM models } \\
\text { from different design } \\
\text { disciplines, provide clash } \\
\text { detection reports, manage }\end{array}$ \\
\hline
\end{tabular}


5. provide technical support for the BIM model during meetings and project implementation.

6. ensure that the BIM deliverables fulfill the quality desired by the employer.

7. complete submissions to national and international BIM-related competitions.

8. operate the BIM platform proficiently and independently.

9. always strive for excellence in terms of improving the efficiency, speed, and security of BIM, and reducing the development cost of the BIM model without additional charges.

10. coordinate BIM model development and manage the schedule and budget of BIM model development.

11. manage the final BIM deliverables during project handover.
4. submit the as-built BIM model within the specified time frame.

5. provide technical support for the BIM model for maintenance and management of the built facility.

6. provide training to the employer's personnel. of quantities (BQ) and the pricing of each item in the BQs.

5. provide the correct types of materials used in the project, impose reasonable control on the use of materials, and ensure that the accuracy of the cost estimation is at least $97 \%$.

6. endeavor to reduce consumption and waste of construction materials.

7. develop a BIM execution plan using the American Institute of Architects LOD or China BIM Standard.

8. manage the BIM platform, ensure that the BIM model is developed according to the model execution plan, produce clash detection reports, and review these reports.

9. develop BIM-related conditions of tendering for selection of contractor, develop BIM technical requirements for the bidders, and prepare standard BIM-related submissions.

10. provide technical support such as programming and data translation to relevant design disciplines involved in the modeling analysis. clashes, and consistently

attend coordination meetings.

5. update the actual construction model on a weekly basis and provide reasonable suggestions.

6. develop his/her own BIM team and provide relevant training to the team.

7. prepare papers for submission to relevant publications, report the results concerning the BIM implementation, assist the contractor to win BIM awards at the provincial, ministerial, and national levels in China, as well as at the international level.

8. assist the contractor in activities related to BIM demonstration and promotion. 
11. provide data translation for various BIM software and resolve interoperability issues between different types of BIM software.

12. provide training to the employer and relevant third parties until they are adept in using the BIM software.

13. update the BIM model and submit clash detection reports within the specified time frame upon receiving instruction of variations from the employer.

14. ensure that the BIM deliverables conform with the format and content required by the employer.

15. provide a two-year warranty to the employer to maintain the BIM model during the operation stage. 
Table IV. Summary of the main findings

\begin{tabular}{|c|c|c|}
\hline No. & Description & Commendable Practices \\
\hline 1. & $\begin{array}{l}\text { Ownership and IPRs of the BIM } \\
\text { model }\end{array}$ & $\begin{array}{l}\text { Project A and Project B have explained the } \\
\text { ownership for the employer clearly. }\end{array}$ \\
\hline 2. & Infringement of copyright & $\begin{array}{l}\text { Project } \mathrm{A} \text {, Project } \mathrm{B} \text { and Project } \mathrm{C} \text { have } \\
\text { clarified and explained the detailed of } \\
\text { indemnity and infringement information for } \\
\text { the employer and the BIM consultant. }\end{array}$ \\
\hline 3. & Roles of the BIM consultant & $\begin{array}{l}\text { The roles varies from one another. Project } \mathrm{C} \\
\text { has more details and specific requirements } \\
\text { (e.g., at least } 97 \% \text { accuracy of cost } \\
\text { estimation) for the roles of the BIM } \\
\text { consultant. }\end{array}$ \\
\hline 4. & $\begin{array}{l}\text { Liability of the BIM consultant in the } \\
\text { event of errors or delays of the BIM } \\
\text { model }\end{array}$ & $\begin{array}{l}\text { Project B and Project D have a clear } \\
\text { calculation on the damages or delay based on } \\
\text { the project circumstances, namely, } 0.1 \% \text { of } \\
\text { the total contract value and } 20 \% \text { of the total } \\
\text { contract value respectively. }\end{array}$ \\
\hline 5. & $\begin{array}{l}\text { Costs and payments related to the use } \\
\text { of BIM in construction projects }\end{array}$ & $\begin{array}{l}\text { All of them do not have specific calculations } \\
\text { for the costs and payments. Yet, Project A } \\
\text { has provided a bit more clarification on what } \\
\text { would be the fees and costs involved. }\end{array}$ \\
\hline
\end{tabular}


